\section{Isolation and Characterization of Microsatellite Loci for the Ornamental Plant Primula obconica Hance (Primulaceae)}

\author{
Hai-fei Yan, Xue-jun Ge, and Chi-ming Hu \\ Key Laboratory of Plant Resources Conservation and Sustainable \\ Utilization, South China Botanical Garden, Chinese Academy of Sciences, \\ Guangzhou 510650, China
}

\section{Gang Hao ${ }^{1}$ \\ South China Agricultural University, Plant Sciences, Wusham, Guangzhou 510642, China}

Additional index words. Primula obconica, ornamental plant, microsatellite markers, polymorphism

\begin{abstract}
Nine microsatellite loci were isolated from Primula obconica using the FIASCO protocol. We used 30 individuals from three populations for the assessment of microsatellite variation. Seven loci were detected with microsatellite polymorphism. The number of alleles per locus ranged from three to seven. The average observed heterozygosity and expected heterozygosity ranged from 0.167 to 0.6 and from 0.409 to 0.653 , respectively. These microsatellite markers will be useful to assess the genetic variation and genetic structure of $\boldsymbol{P}$. obconica.
\end{abstract}

The genus Primula L. comprises $\approx 500$ species mainly native to temperate and mountainous regions of the Northern Hemisphere, whereas 300 of them are distributed in China (Hu and Kelso, 1996). Many species of Primula are ideal ornamental plants for their bright and colorful flowers. As a result of its number of species and popularity, the genus has been regarded as one of the most popular and greatest horticultural plant groups (Richards, 2002). In China, Primula together with Rhododendron L. and Gentiana L. have been known as the three most famous alpine flowers. The abundance of the genus in China offers an important resource for horticultural exploration and cultivation. Approximately 110 species of the genus were introduced to western countries from China since the end of the 19th century, and many of them have been cultivated for their attractive flowers as pot plants (Hu, 1990; Hu and Kelso, 1996).

Like many other popular primulas, $P$. obconica Hance, a native perennial herb in China, has become a very popular ornamental flower all over the world since it was first introduced to the United Kingdom in 1880 (Connolly et al., 2004). P. obconica mainly grows in moist thickets and deciduous forests between 500 and $3000 \mathrm{~m}$ elevation. The species has been known as a unique one in the

Received for publication 1 Oct. 2009. Accepted for publication 22 Nov. 2009.

This study was supported by the National Natural Science Foundation of China (Nos. 40671066, 30870171, and 30900160).

${ }^{1}$ To whom reprint requests should be addressed; e-mail haogang@scau.edu.cn. genus that has a distribution pattern of penetrating to the subtropical eastern coast from southwestern China. The broad range of the species implies substantial adaptations to varying habitats, which might be one of the key factors making it the most suitable for indoor cultivation such as its remarkable tolerance of modern central heating described by Christensen and Larsen (2000). However, opposite to its attractive flowers, $P$. obconica is the most allergenic among primulas and has long been known as a poisonous plant (Christensen and Larsen, 2000). Fortunately, Nan et al. (2002) pointed out that two key allergic compounds were not extracted from wild individuals of $P$. obconica, suggesting that wild ones might be a potential resource for horticultural uses. Besides, attention to its adaptation to various habitats will facilitate discovering and cultivating more new horticultural characteristics. Nuclear microsatellite loci are powerful markers for studies of population genetics because of their high polymorphism, codominant transmission, and presumably neutral and extensive genome coverage (Powell et al., 1996). We report the isolation and characterization of a set of polymorphic microsatellite loci from the genome of $P$. obconica to investigate the population genetic diversity and genetic structure, which is very important for studying its adaptation and evaluating its genetic resources.

Total genomic DNA was extracted from one individual of $P$. obconica from Hubei province (long. $30^{\circ} 53^{\prime} \mathrm{N}$, lat. $111^{\circ} 20^{\prime} \mathrm{E}$ ), which is located in central China. Two enriched microsatellite libraries $\left[(\mathrm{AC})_{15}\right.$ and $(A G)_{15}$ ] were constructed according to the FIASCO protocol described by Zane et al.
(2002). Polymerase chain reaction (PCR) products were ligated into PMD-18 vectors (TaKaRa, Dalian, China) and were transformed into competent cells JM109 (TaKaRa). A total of 85 positive clones with more than a 500-bp target amplicon were sequenced in a 3700 DNA Analysis System (PE Applied Biosystems, Foster City, CA). Thirty-one sequences with microsatellite repeats $(36 \%)$ were used to design primers by Primer Version 3.0 (Rozen and Skaletsky, 2000). The PCR mixture in a $20 \mu \mathrm{L}$ volume contained 3 to $10 \mathrm{ng}$ of template DNA, 1× PCR buffer $\left(\mathrm{MgCl}_{2}\right.$ free, TaKaRa), $0.3 \mu \mathrm{m}$ of each primer (Table 1), $1.5 \mathrm{~mm}$ of $\mathrm{MgCl}_{2}, 0.2$ $\mathrm{mm}$ of each $\mathrm{dNTP}$, and $1 \mathrm{U}$ Taq polymerase (TaKaRa). The PCR reaction underwent an initial 3-min denaturation step at $94{ }^{\circ} \mathrm{C}$ followed by 35 cycles of $30 \mathrm{~s}$ at $94{ }^{\circ} \mathrm{C}, 30 \mathrm{~s}$ at locus-specific annealing temperature, $30 \mathrm{~s}$ at $72{ }^{\circ} \mathrm{C}$, and a final extension at $72{ }^{\circ} \mathrm{C}$ for $5 \mathrm{~min}$ (Table 1). Amplicons were checked on $2 \%$ agarose gel stained with ethidium bromide. PCR products with robust and specific amplification were further separated on $6 \%$ polyacrylamide denaturing gel and visualized by silver staining. Fragments were scored in favor of a 25-bp ladder (Promega, Madison, WI).

Nine loci amplified with a single band visualized on $2 \%$ agarose gel could be further assessed for allelic polymorphism. Of nine loci, seven polymorphic microsatellite loci were revealed from $30 \mathrm{P}$. obconica individuals among three natural populations (10 individuals from each population), which were collected from Hunan province (long. $29^{\circ} 33^{\prime}$ $\mathrm{N}$, lat. $109^{\circ} 59^{\prime} \mathrm{E}$ ), Hubei province (long. $30^{\circ} 53^{\prime} \mathrm{N}$, lat. $111^{\circ} 20^{\prime} \mathrm{E}$ ), and Chongqing municipality (long. $29^{\circ} 02^{\prime} \mathrm{N}$, lat. $107^{\circ} 12^{\prime} \mathrm{E}$ ) in central China. The number of alleles ranged from three to seven with an average of 4.3 per locus. Observed $\left(\mathrm{H}_{\mathrm{O}}\right)$ and expected $\left(\mathrm{H}_{\mathrm{E}}\right)$ heterozygosities were calculated by GENEPOP version 4.3 (Raymond and Rousset, 1995). The same software was also used to test deviations from Hardy-Weinberg equilibrium (HWE) and linkage disequilibrium (LD) between pairs of loci.

The $\mathrm{H}_{\mathrm{O}}$ and $\mathrm{H}_{\mathrm{E}}$ heterozygosities ranged from 0.167 to 0.6 and 0.409 to 0.653 (Table $1)$, respectively. Five loci of seven loci showed a significant departure from HWE as a result of heterozygote deficiency. Inbreeding, Wahlund effects, selection against heterozygotes, and null alleles could cause an excessive number of homozygotes (Hartl and Clark, 1997; Pemberton et al., 1995). Given has $P$. obconica with a heteromorphic selfincompatibility system (Stevens and Murray, 1981, 1982), we consider inbreeding not the main reason for the heterozygote deficiency. However, Wahlund effect is at least in part responsible for the heterozygote deficiency, because the three populations belong to two lineages, which might cause different allele frequencies among populations (Yan et al., 2007). Evidence of a possible null allele at loci Po38 and Po123 were detected by using MICRO-CHECKER 2.2.3 with a frequency from 0.244 to 0.6396 and from 0.3288 to 1 , respectively (Van Oosterhout et al., 2004). 
Table 1. Primer sequences and characterization for nine microsattllite loci isolated from Primula obconica.

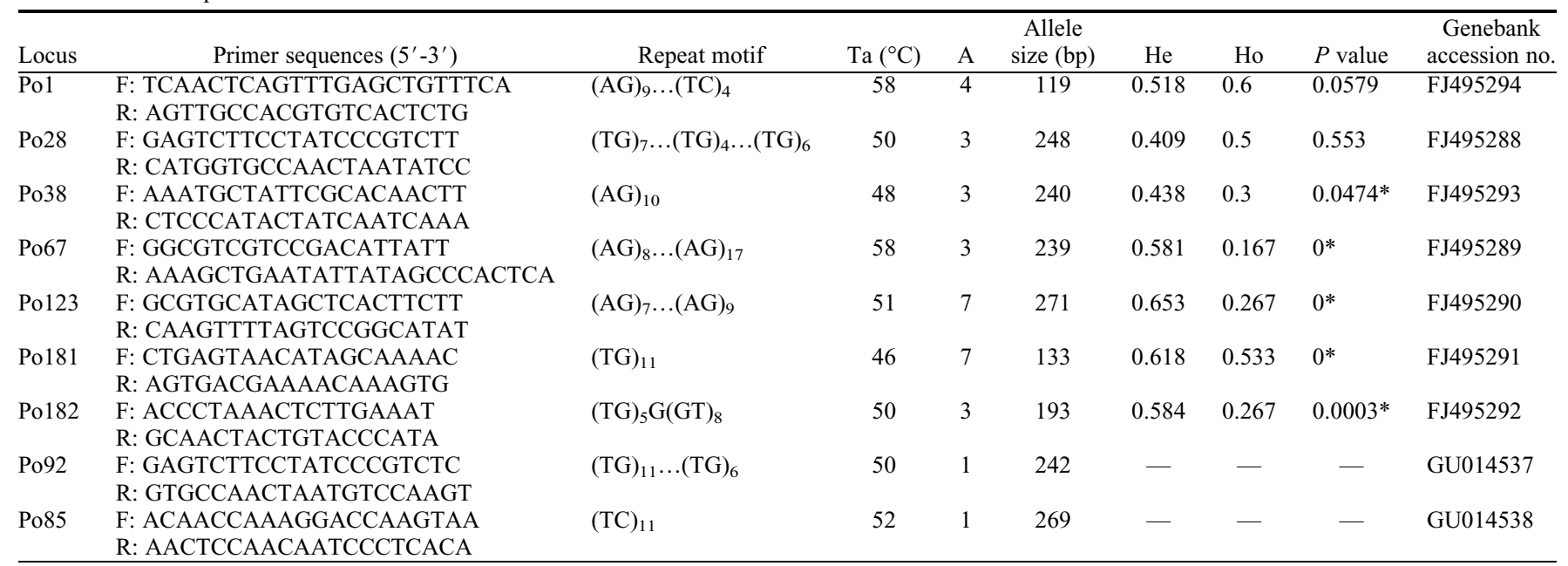

$\mathrm{Ta}=$ annealing temperature; $A=$ number of alleles observed; $\mathrm{H}_{\mathrm{O}}=$ observed heterozygosity; $\mathrm{H}_{\mathrm{E}}=$ expected heterozygosity.

*The observed heterozygosity is significantly different from the expected heterozygosity under Hardy-Weinberg equilibrium after correction for multiple test $(P<0.007)$.

Significant LD at the species was detected in 12 of 21 possible locus pairs with multiple tests $(P<0.007)$, whereas no significant LD was detected at the population level. The high LD may be the result of the significant genetic differentiation among these populations. Two monomorphic loci (Po85 and Po92) will be further assessed for polymorphisms in our ongoing study, especially for those populations from southwest China, which were found to possess relatively high levels of genetic diversity by chloroplast simple sequence repeat markers (Yan et al., 2007). We anticipate that the microsatellite loci described here will be useful to evaluate the genetic variation of $P$. obconica and provide appropriate management decisions for using the genetic resource.

\section{Literature Cited}

Christensen, L.P. and E. Larsen. 2000. Direct emission of the allergen primin from intact Primula obconica plants. Contact Dermatitis 42:149-153.

Connolly, M., J. McCune, E. Dauncey, and C.R. Lovell. 2004. Primula obconica-is contact allergy on the decline? Contact Dermatitis 51:167-171.
Hartl, D.L. and A.G. Clark. 1997. Principles of population genetics. 3rd Ed. Sinauer Associates, Sunderland, MA.

Hu, C.M. 1990. Primulaceae, p. 1-2. In: Chen, F.H. and C.M. Hu (eds.). Flora Reipublicae Popularis Sinicae, Tomus 59(2). Science Press, Beijing, China.

Hu, C.M. and S. Kelso. 1996. Primulaceae, p. 100 In: Wu, Z.Y. and P.H. Raven (eds.). Flora of China. Vol. 15. Science Press and Missouri Botanical Garden Press, Beijing, China, and St. Louis, MO

Nan, P., S.L. Peng, Y.H. Zhang, and Y. Zhong. 2002. Composition of volatile oil of Primula obconica in central China. Nat. Prod. Lett. 16:249-253.

Pemberton, J.M., D.R. Bancroft, and J.A. Barrerr. 1995. Nonamplifying alleles at microsatellite loci: A caution for parentage and population studies. Mol. Ecol. 4:249-252.

Powell, W., G.C. Machray, and J. Provan. 1996 Polymorphism revealed by simple sequence repeats. Trends Plant Sci. 1:215-222.

Raymond, M. and F. Rousset. 1995. GENEPOP (version 1.2): Population genetics software for exact tests and ecumenicism. J. Hered. 86:248249.

Richards, A.J. 2002. Primula. 2nd Ed. Timber Press, Portland, OR.
Rozen, S. and H.J. Skaletsky. 2000. Primer 3.0 on the WWW for general users and for biologist programmers, p. 365-386. In: Krawetz, S. and S. Misener (eds.). Bioinformatics methods and protocols: Methods in molecular biology. Humana Press, Totowa, NJ.

Stevens, V.A.M. and B.G. Murray. 1981. Studies on heteromorphic self-incompatibility systems: The cytochemistry and ultrastructure of the tapetum of Primula obconica. J. Cell Sci. 50: 419-431.

Stevens, V.A.M. and B.G. Murray. 1982. Studies on heteromorphic self-incompatibility systems: Physiological aspects of the incompatibility system of Primula obconica. Theor. Appl. Genet. 61:245-256.

Van Oosterhout, C., W.F. Hutchinson, D.P.M. Wills, and P. Shipley. 2004. MICROCHECKER: Software for identifying and correcting genotyping errors in microsatellite data. Mol. Ecol. Notes 4:535-538.

Yan, H.F., C.I. Peng, C.M. Hu, and G. Hao. 2007. Phylogeographic structure of Primula obconica (Primulaceae) inferred from chloroplast microsatellites (cpSSRs) markers. Acta Phytotaxon. Sin. 45:488-496.

Zane, L., L. Bargelloni, and T. Patarnello. 2002. Strategies for microsatellite isolation: A review. Mol. Ecol. 11:1-16. 